\title{
The Hand and Environment (2)
}

- Physiological Changes of Digital Functions between Two Age Groups by Cold Water Immersions and Climatic Conditions-

\author{
Katsumi SuzUKI ${ }^{1}$, Masateru IJICHI ${ }^{1}$, Takayuki MATSUKI ${ }^{1}$, Akio SEKI ${ }^{1}$, \\ Hiromichi TANAKA ${ }^{1}$, Kohichi MONJI ${ }^{2}$ and Kiyoharu NAKASHIMA ${ }^{2}$ \\ ${ }^{1}$ Department of Orthopaedic Surgery, School of Medicine, University of Occupational and \\ Environmental Health, Japan. Kitakyushu 807, Japan \\ ${ }^{2}$ Climatic Chamber, School of Medicine, University of Occupational and Environmental Health, \\ Japan. Kitakyushu 807, Japan
}

Abstract: Various functions of the hand have been evaluated by quantitative expressions. However, how these normal numerical data change with various environmental and individual conditions has been scarcely reported. Here, the authors have undertaken several basic experiments. Of various functions of the hand, three indicators namely, digital temperature, vibratory sensibility and pinch strength, all of which have been utilized clinically by the authors were selected. As environmental conditions two room conditions $\left(10^{\circ} \mathrm{C}\right.$ with $50 \%$ humidity and $30^{\circ} \mathrm{C}$ with $50 \%$ humidity) were maintained. As a stress test, cold water immersions were undertaken on 21 healthy male adults (an older age group contained 10 persons and the younger age group 11 persons) at each room condition. Digital temperatures of the older age group seemed to be slightly higher than the younger age group. The immersed fingers recovered more smoothly in the $30^{\circ} \mathrm{C}$ room within 40 minutes than in the $10^{\circ} \mathrm{C}$ room. Pinch strengths of the immersed fingers were reduced by the immersions, significantly in the $10^{\circ} \mathrm{C}$ room. Vibratory sensibilities became lowered in the immersed fingers.

Key words: digital temperature, pinch strength, vibratory sensibility, cold water immersion, physiological data.

(Received 16 July 1981)

\section{Introduction}

Recently, from the standpoint of clinical evaluations or follow up studies, there is a tendency for various functions of the hand to be recorded and evaluated by quantitative expressions, especially in vibration syndromes or in neurorrhaphies etc.

Unfortunately, however, how these normal numerical data change with various environmental and individual conditions has been scarcely reported in orthopaedic practices.

Here, the authors undertook several basic experiments (Suzuki et al., 1981). In order to obtain numerical data, three indicators namely, digital temperature, vibratory sensibility and pinch strength, all of which have been utilized clinically by the authors were selected. As environmental conditions, two room temperatures $\left(10^{\circ} \mathrm{C}\right.$ with $50 \%$ humidity and $30^{\circ} \mathrm{C}$ with $50 \%$ humidity) were maintained in an artificial climatic chamber. And as 
a stress test, cold water immersions were undertaken on all persons at each chamber temperature. Data obtained from 21 healthy persons who were classified in two age groups are reported and discussed in this paper.

\section{Materials and Methods}

A. Twenty one healthy male adults were studied in the experiment, which was undertaken in the winter of 1979. These persons were classified into two age groups, that is, an older age group (10 persons, mean $43.2 \pm 3.4$ years) and a younger age group (11 persons, mean $25.5 \pm 1.7$ years) (Table 1 ).

Each person to be studied ate a 680-calorie lunch at noon. After evacuating their bladders, they put on 1.8 clo of clothings. Then, at $1.00 \mathrm{p.m}$., they entered a climatic chamber which was kept at $10^{\circ} \mathrm{C}$ and $50 \%$ humidity and sat quietly for 30 minutes.

B. In order to record digital temperatures, tiny thermisters $(0.8 \mathrm{~cm}$ in diameter, manufactured by Nihon Keisokuki Co.) were fixed comfortably on the dorsal surface of the proximal part of the terminal phalanx with adhesive plasters. Digital temperatures were measured only on the middle and ring fingers of both hands and recorded by an electronic automatic balanced recorder (manufactured by Nihon Keisokuki Co., Type $\mathrm{EH}-300-12)$.

When 30 minutes had elapsed since the person entered the chamber and digital temperatures were stabilized, the numerical data were measured. Vibratory sensibility was recorded in $\mathrm{dB}$ by stimulating a vibratory sensibility meter (manufactured by Rion Co., Type AU-02) at 125 and $250 \mathrm{~Hz}$ on the pulp of the terminal phalanges of both index fingers. Pinch strength was measured in $\mathrm{kg}$ by a pinch gauge (manufactured by J.A. Preston Co.) placed between the pulps of the thumb and the index finger, both of which were extended at the interphalangeal joints, of the right and left hands.

After obtaining these preliminary data, the right hand was immersed up to the wristjoint level in $6.5^{\circ} \mathrm{C}$ water bath which was controlled and stirred softly in a circulating water cooler (manufactured by Yamato Kagaku Co.), for 10 minutes.

The immersed right hand was drawn out and blotted dry on a towel. The digital temperatures, the pinch strengths and vibratory sensibilities of both hands were measured at $0,5,10,15$, and 20 minutes after finishing immersion.

Table 1. Physical characteristics (mean \pm s. D.) of the subjects

\begin{tabular}{lcccc}
\hline Subject group (No. exam.) & Age (years) & Height (cm) & Body weight $(\mathrm{kg})$ \\
\hline Younger & $(11)$ & $25.5 \pm 1.7$ & $168.2 \pm 3.8$ & $59.4 \pm 4.7$ \\
Older & $(10)$ & $43.2 \pm 3.4$ & $165.0 \pm 7.1$ & $68.4 \pm 11.4$ \\
Paired t test & & $P<0.001$ & n. s & $P<0.02$ \\
\hline
\end{tabular}


C. Then, when the chamber temperature was changed to $30^{\circ} \mathrm{C}$ with the same 50 percent humidity and the water bath was set at $11^{\circ} \mathrm{C}$, the above procedures were repeated.

These data were tabulated as a mean \pm standard deviation and tested by a paired $t$ test or a Fischer's direct calculation method in this paper.

\section{Results}

A. In the $10^{\circ} \mathrm{C}$ chamber

The digital temperatures of the older age group tended to be a little higher than those of the younger age group, as shown in Table 2. As a result of the immersion, cold vasodilatations (hunting reactions) were observed only in three persons in each group. These thermal changes are summarized in Figs. 1 and 2. Unexpectedly, the temperatures of the immersed fingers recovered slowly in both groups and even after 40 minutes, they did not recover in six cases in each group. On the left side, the digital temperatures were also lowered as a result of the immersion and did not recover within 25 minutes.

The pinch strengths were reduced as a result of the immersions especially in the right hands of both groups, as shown in Table 3. These changes are also shown in Fig. 3. In almost all cases of immersed hands, they did not recover within 20 minutes.

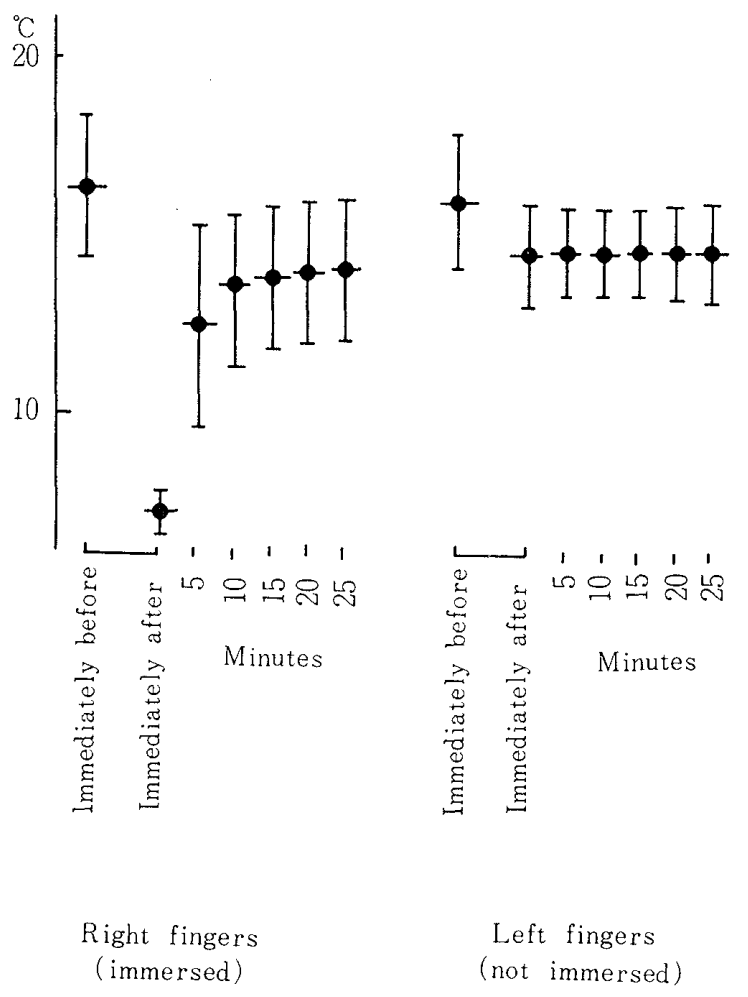

Fig. 1. Changes of digital temperatures $\left({ }^{\circ} \mathrm{C}\right)$ through cold water immersions $\left(6.5^{\circ} \mathrm{C}\right)$ in $10^{\circ} \mathrm{C}$ chamber. A. Younger age group ( $\mathrm{n}: 11)$. 
Table 2. Pre- and post-immersion digital temperatures (mean \pm S. D. ) in $10^{\circ} \mathrm{C}$ room

\begin{tabular}{|c|c|c|c|c|c|}
\hline \multirow[b]{2}{*}{ Subject group (No. } & \multirow[b]{2}{*}{ exam. ) } & \multirow[b]{2}{*}{ Hand } & \multicolumn{3}{|c|}{ Water temperature $\left(6.5^{\circ} \mathrm{C}\right)$} \\
\hline & & & Pre-immersion & Post-immersion & Paired $t$ test \\
\hline \multirow[t]{3}{*}{ Younger } & (11) & Right (immersed) & $16.3 \pm 2.1$ & $7.3 \pm 0.6$ & $P<0.001$ \\
\hline & & Left & $15.9 \pm 1.8^{*}$ & $14.5 \pm 1.4$ & $P<0.05$ \\
\hline & & Paired $\mathrm{t}$ test & n.s. & $P<0.001$ & \\
\hline \multirow[t]{3}{*}{ Older } & $(10)$ & Right (immersed) & $19.0 \pm 4.3$ & $7.5 \pm 0.7$ & $P<0.001$ \\
\hline & & Left & $18.4 \pm 3.4^{*}$ & $16.6 \pm 3.2$ & $P<0.001$ \\
\hline & & Paired $\mathrm{t}$ test & n. s. & $P<0.001$ & \\
\hline
\end{tabular}

$* P<0.05$

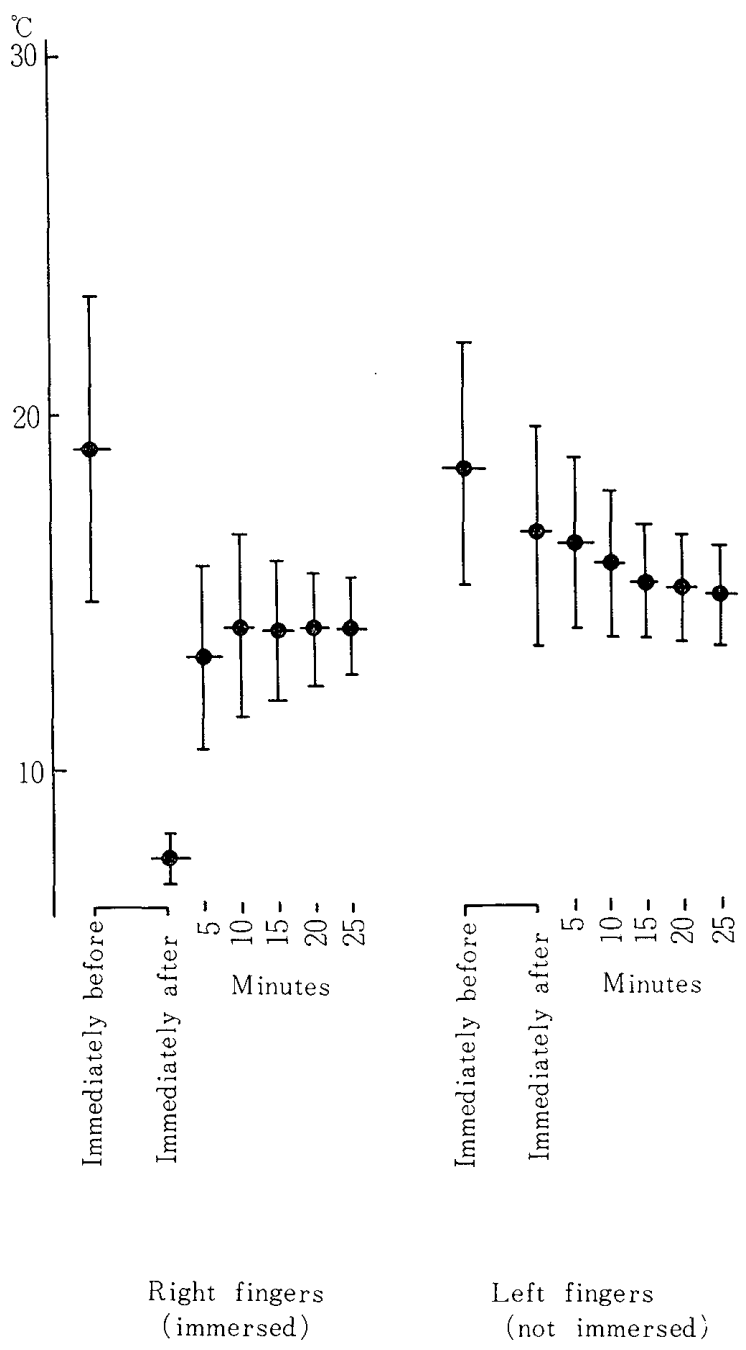

Fig. 2. Changes of digital temperatures $\left({ }^{\circ} \mathrm{C}\right)$ through cold water immersions $\left(6.5^{\circ} \mathrm{C}\right)$ in $10^{\circ} \mathrm{C}$ chamber. B. Older age group $(n: 10)$. 
Table 3. Pre- and post-immersion pinch strength (mean $\mathrm{kg} \pm \mathrm{S} . \mathrm{D}$.) in $10^{\circ} \mathrm{C}$ room

\begin{tabular}{cclccc}
\hline Subject group & (No. exam.) & \multicolumn{1}{c}{ Hand } & Pre-immersion & Post-immersion & Paired t test \\
\hline Younger & \multirow{2}{*}{$(11)$} & Right (immersed) & $5.2 \pm 1.4$ & $3.5 \pm 0.8$ & $P<0.01$ \\
& & Left & $5.2 \pm 1.3$ & $4.8 \pm 0.6$ & n.s. \\
& & Paired t test & n.s. & n.s. & \\
Older & \multirow{2}{*}{$(10)$} & Right (immersed) & $5.4 \pm 0.9$ & $3.7 \pm 2.5$ & $P<0.02$ \\
& & Left & $5.1 \pm 1.6$ & $4.6 \pm 0.8$ & n.s. \\
& Paired t test & n.s. & n.s. & \\
\hline
\end{tabular}

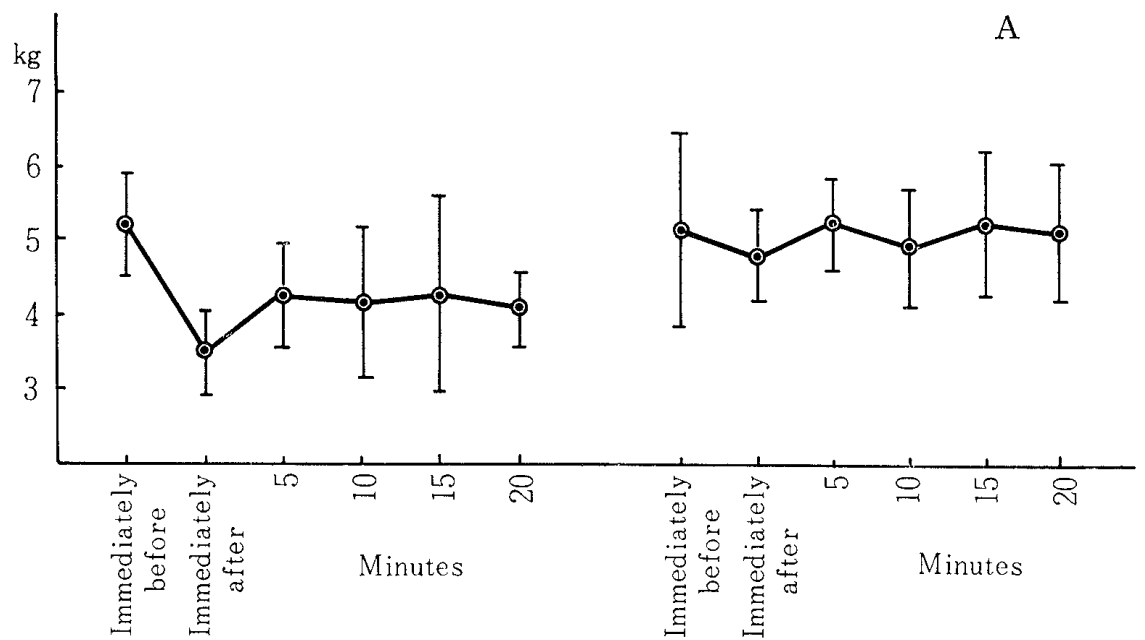

Right hand (immersed) Left hand (not immersed)

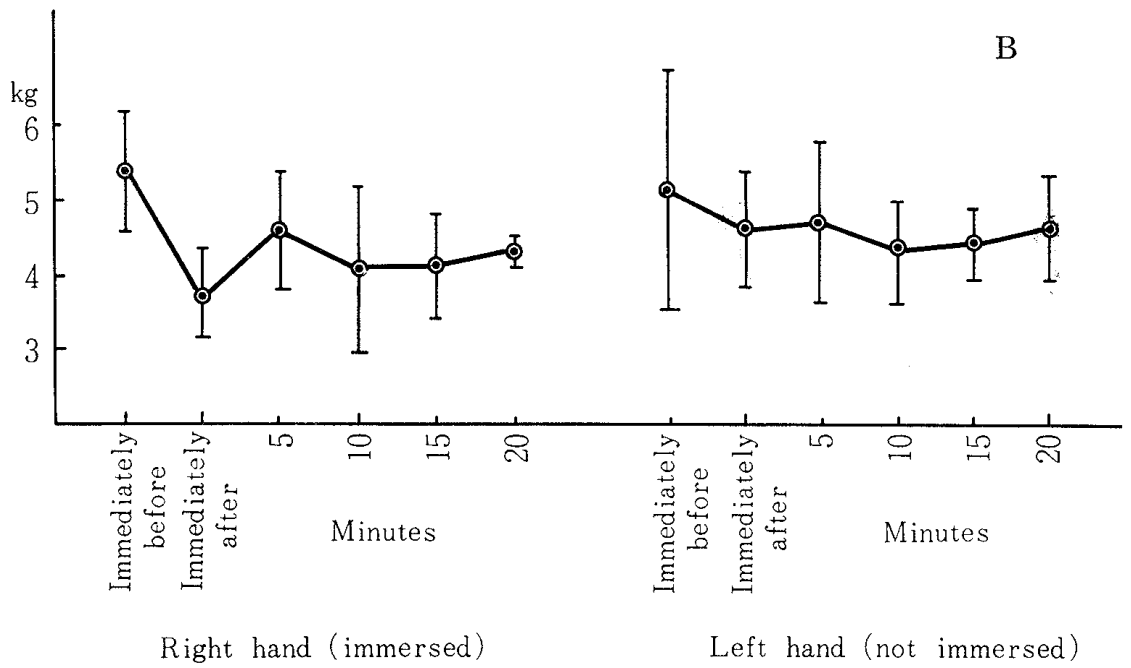

Fig. 3. Changes of pinch strength through cold water immersions in $10^{\circ} \mathrm{C}$ chamber. A. Younger age group (n:11), B. Older age group (n:10). 
Table 4. Pre- and post-immersion vibratory sensibilities (mean $\mathrm{dB} \pm$ s. D.) at 125 $\mathrm{Hz}$ in $10^{\circ} \mathrm{C}$ room

\begin{tabular}{|c|c|c|c|c|c|}
\hline Subject group & (No. exam.) & Hand & Pre-immersion & Post-immersion & Paired $t$ test \\
\hline \multirow[t]{3}{*}{ Younger } & (11) & Right (immersed) & $3.6 \pm 9.1$ & $12.7 \pm 8.4$ & $P<0.02$ \\
\hline & & Left & $3.6 \pm 7.3$ & $10.9 \pm 4.1$ & $P<0.001$ \\
\hline & & Paired $t$ test & n.s. & n.s. & \\
\hline \multirow[t]{3}{*}{ Older } & $(10)$ & Right (immersed) & $2.0 \pm 6.4$ & $16.3 \pm 4.2$ & $P<0.001$ \\
\hline & & Left & $-0.3 \pm 4.9$ & $9.3 \pm 8.1$ & $P<0.001$ \\
\hline & & Paired $t$ test & n. s. & $P<0.02$ & \\
\hline
\end{tabular}

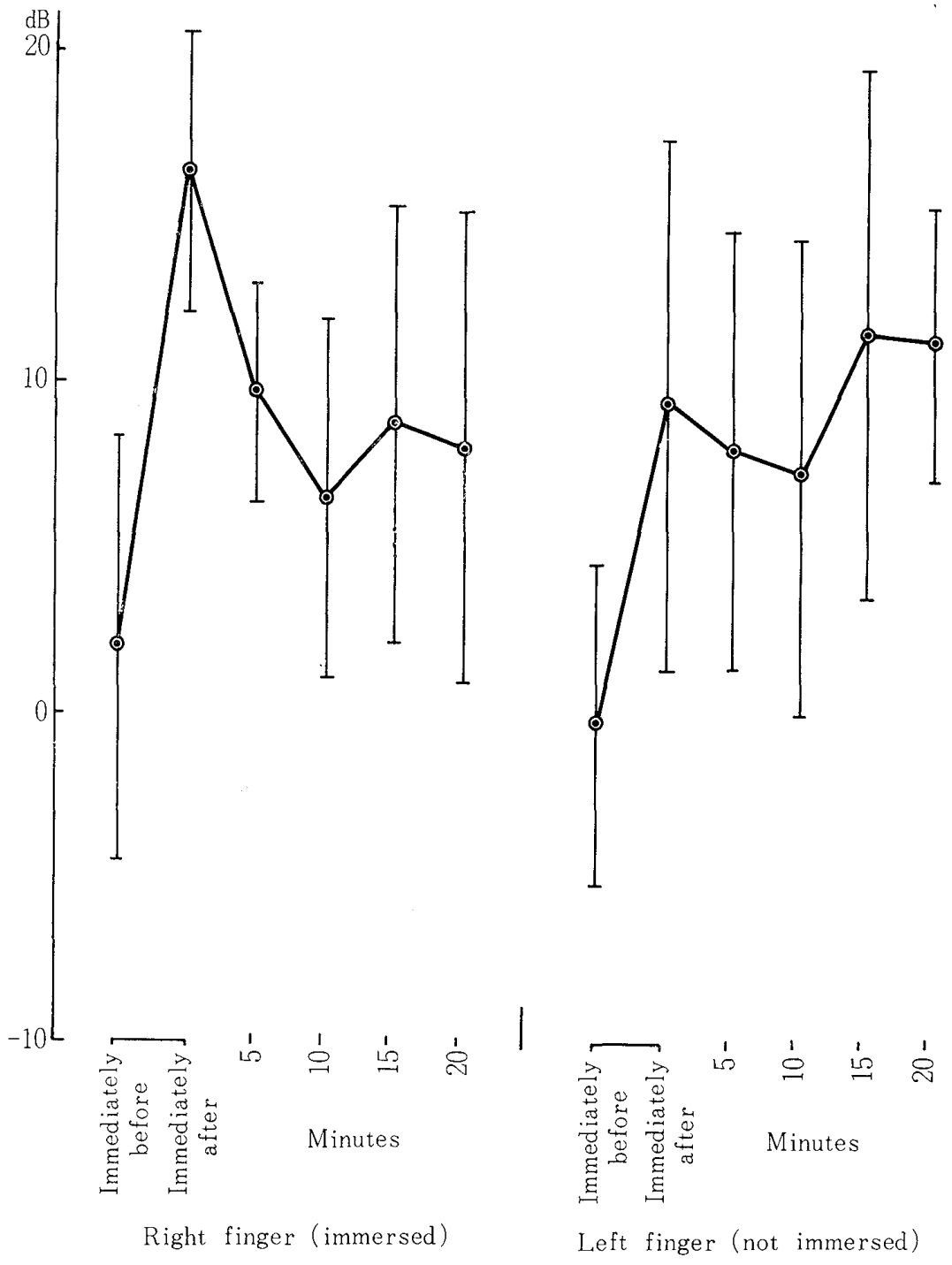

Fig. 4. Changes of vibratory sensibilities (at $125 \mathrm{~Hz}$ ) through cold water immersions in $10^{\circ} \mathrm{C}$ chamber.

B. Older age group $(n: 10)$. 
Table 5. Pre- and post-immersion vibratory sensibilities (mean $\mathrm{dB} \pm \mathrm{s}$. D.) at $250 \mathrm{~Hz}$ in $10^{\circ} \mathrm{C}$ room

\begin{tabular}{cclccc} 
Subject group & (No. exam.) & \multicolumn{1}{c}{ Hand } & Pre-immersion & Post-immersion Paired test \\
\hline Younger & $(11)$ & Right (immersed) & $14.3 \pm 10.4$ & $17.1 \pm 12.7$ & n. s. \\
& & Left & $14.1 \pm 11.7$ & $16.4 \pm 9.4$ & n.s. \\
& & Paired t test & n.s. & n.s. & \\
Older & \multirow{2}{*}{$(10)$} & Right (immersed) & $11.8 \pm 6.5$ & $24.0 \pm 8.8$ & $P<0.02$ \\
& & Left & $6.3 \pm 5.7$ & $17.3 \pm 8.7$ & $P<0.001$ \\
& & Paired t test & $P<0.1$ & n.s. & \\
\hline
\end{tabular}

The vibratory sensibilities ( $\mathrm{dB}$ at $125 \mathrm{~Hz}$ ) were significantly lowered by the immersions, as shown in Table 4. These changes of the older age group are summarized in Fig. 4, and these recoveries were retarded.

The vibratory sensibilities ( $\mathrm{dB}$ at $250 \mathrm{~Hz}$ ) were lowered by the immersions, significantly in the older age group, as shown in Table 5. They did not recover within 20 minutes in almost all cases in both groups.

B. In the $30^{\circ} \mathrm{C}$ chamber

The digital temperatures of the older age group were a little higher than those of the younger age group, as shown in Table 6 . As a result of the immersions, hunting reactions were observed in four persons in the younger age group and in two in the older age group. These thermal changes are summarized in Figs. 5 and 6 . They recovered within 40 minutes in all cases (Table 10).

The pinch strengths were reduced slightly by the immersions, except for the left hands of the older age group, as shown in Table 7 . They recovered within 20 minutes in four cases of the younger age group and in six in the older age group (Table 11).

The vibratory sensibilities $(\mathrm{dB}$ at $125 \mathrm{~Hz}$ ) were significantly lowered in the right fingers as a result of the immersions, as shown in Table 8 . These changes were also summarized in Figs. 7 and 8 . They recovered within 20 minutes in almost all cases in both groups, as shown in Tables 12 and 13.

The vibratory sensibilities $(\mathrm{dB}$ at $250 \mathrm{~Hz}$ ) were significantly lowered in the right fingers as a result of the immersions, as shown in Table 9. These changes of the younger age group are summarized in Fig. 9. They recovered within 20 minutes in almost all cases in both groups, as shown in Tables 14 and 15. 
Table 6. Pre- and post-immersion digital temperatures (mean \pm S. D. ) in $30^{\circ} \mathrm{C}$ room

\begin{tabular}{|c|c|c|c|c|c|}
\hline \multirow[b]{2}{*}{ Subject group } & \multirow[b]{2}{*}{ (No. exam.) } & \multirow[b]{2}{*}{ Hand } & \multicolumn{3}{|c|}{ Water temperature $\left(11^{\circ} \mathrm{C}\right)$} \\
\hline & & & Pre-immersion & Post-immersion & Paired $\mathrm{t}$ test \\
\hline \multirow[t]{3}{*}{ Younger } & (11) & Right (immersed) & $33.5 \pm 1.2$ & $11.7 \pm 0.7$ & $P<0.001$ \\
\hline & & Left & $32.4 \pm 1.3$ & $31.6 \pm 1.0^{*}$ & n.s. \\
\hline & & Paired $\mathrm{t}$ test & n.s. & $P<0.001$ & \\
\hline \multirow[t]{3}{*}{ Older } & $(10)$ & Right (immersed) & $34.0 \pm 0.7$ & $12.1 \pm 0.6$ & $P<0.001$ \\
\hline & & Left & $33.6 \pm 0.6$ & $33.1 \pm 1.1^{*}$ & n.s. \\
\hline & & Paired $\mathrm{t}$ test & n.s. & $P<0.001$ & \\
\hline
\end{tabular}

$* P<0.01$

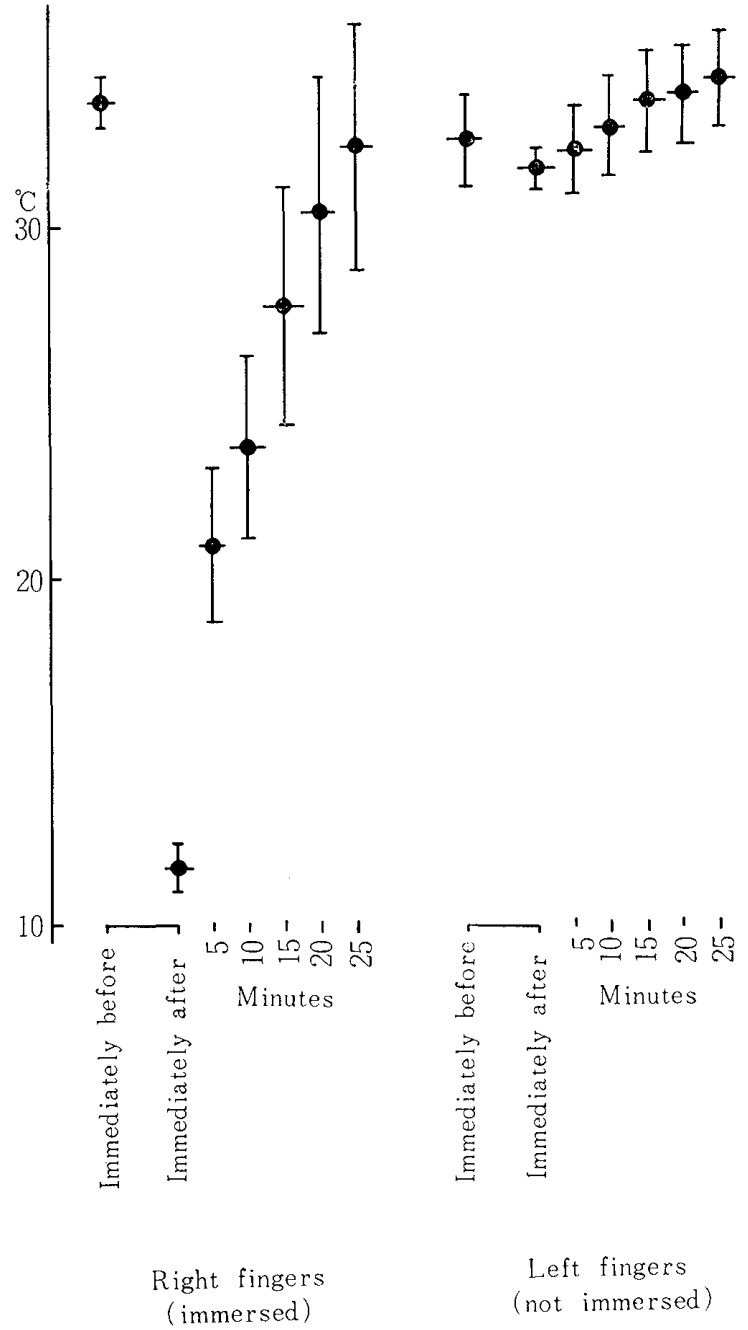

Fig. 5. Changes of digital temperatures $\left({ }^{\circ} \mathrm{C}\right)$ through cold water immersions in $30^{\circ} \mathrm{C}$ chamber. Younger age group ( $n: 11)$. 
Table 7. Pre- and post-immersion pinch strengths (mean $\mathrm{kg} \pm \mathrm{s} . \mathrm{D}$.) in $30^{\circ} \mathrm{C}$ room

\begin{tabular}{|c|c|c|c|c|c|}
\hline Subject group & (No. exam.) & Hand & Pre-immersion & Post-immersion & Paired $t$ test \\
\hline \multirow[t]{3}{*}{ Younger } & (11) & Right (immersed) & $5.1 \pm 2.6$ & $4.1 \pm 0.9$ & n. s. \\
\hline & & Left & $4.9 \pm 0.9$ & $4.5 \pm 0.8$ & n. s. \\
\hline & & Paired $\mathrm{t}$ test & n.s. & n. s. & \\
\hline \multirow[t]{3}{*}{ Older } & $(10)$ & Right (immersed) & $4.3 \pm 0.9$ & $4.2 \pm 0.6$ & n. s. \\
\hline & & Left & $4.3 \pm 0.7$ & $4.5 \pm 1.2$ & n. s. \\
\hline & & Paired $\mathrm{t}$ test & n. s. & n. s. & \\
\hline
\end{tabular}

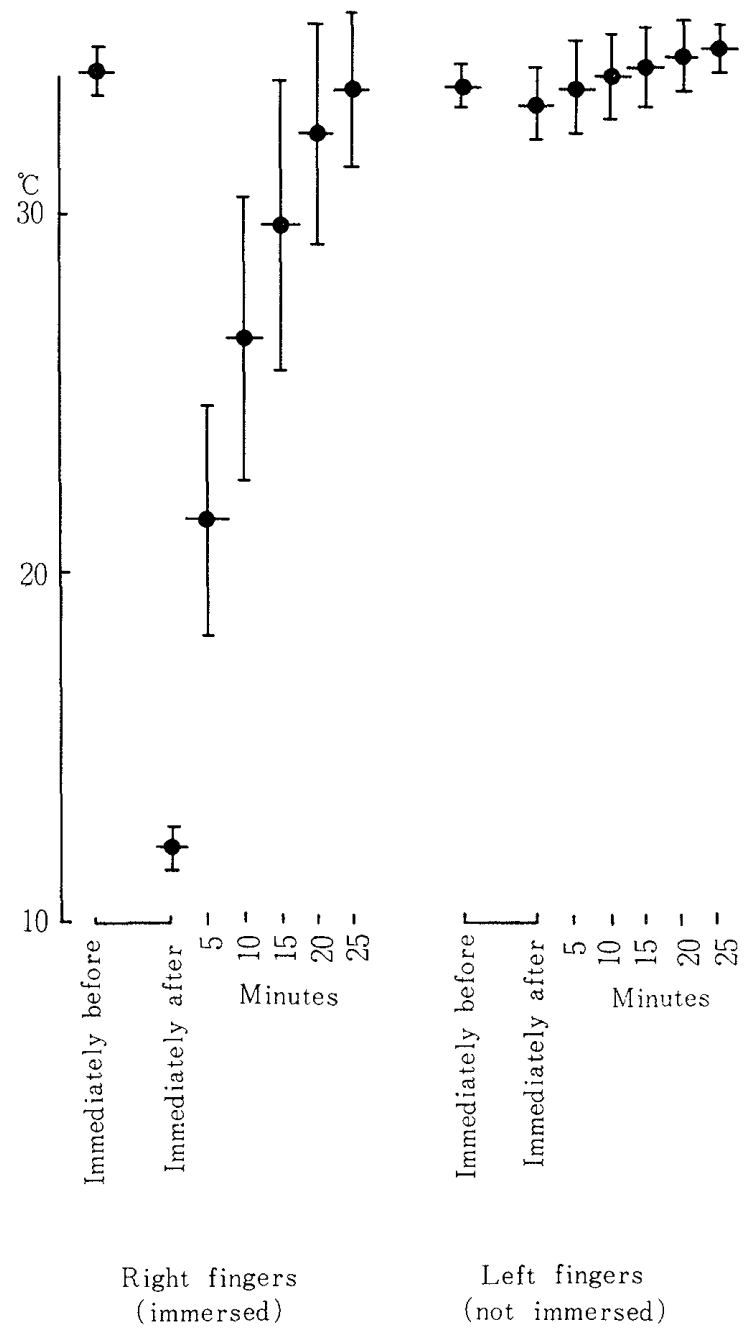

Fig. 6. Changes of digital temperatures $\left({ }^{\circ} \mathrm{C}\right)$ through cold water immersions in $30^{\circ} \mathrm{C}$ chamber. Older age group $(n: 10)$. 
Table 8. Pre- and post-immersion vibratory sensibilities (mean $\mathrm{dB} \pm \mathrm{s}$. D.) at $125 \mathrm{~Hz}$ in $30^{\circ} \mathrm{C}$ room

\begin{tabular}{cccccc}
\hline Subject group & (No. exam.) & Hand & Pre-immersion & Post-immersion & Paired t test \\
\hline Younger & \multirow{2}{*}{ (11) } & Right (immersed) & $-1.4 \pm 4.2$ & $14.8 \pm 6.6$ & $P<0.001$ \\
& & Left & $-3.2 \pm 3.6$ & $0.5 \pm 3.5$ & n.s. \\
& & Paired t test & n.s. & $P<0.001$ & \\
Older & \multirow{2}{*}{$(10)$} & Right (immersed) & $0.5 \pm 5.5$ & $15.5 \pm 7.0$ & $P<0.001$ \\
& & Left & $0 \pm 5.7$ & $0.3 \pm 5.3$ & n.s. \\
& Paired t test & n.s. & $P<0.001$ & \\
\hline
\end{tabular}

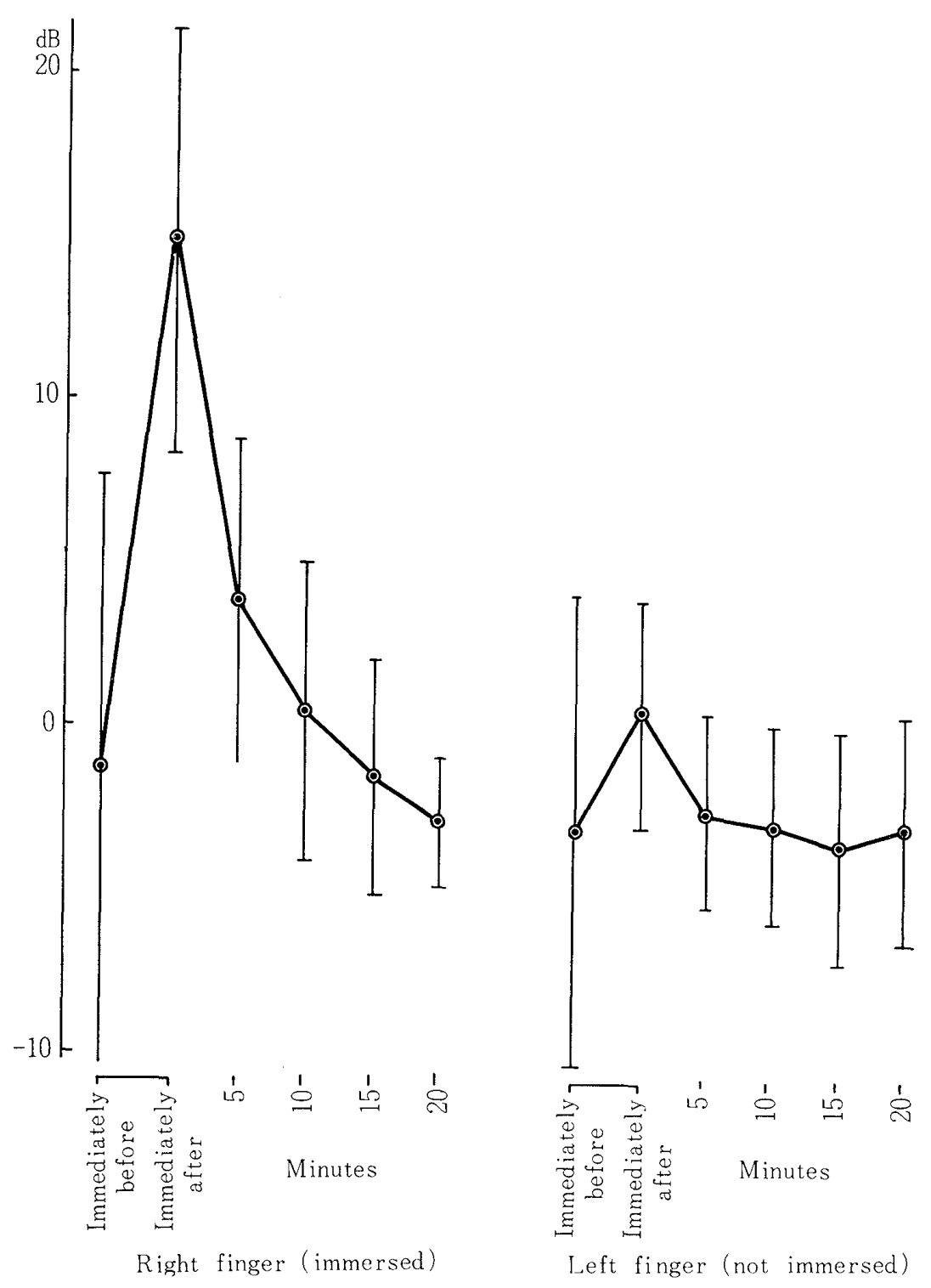

Fig. 7. Changes of vibratory sensibilities (at $125 \mathrm{~Hz}$ ) through cold water immersions in $30^{\circ} \mathrm{C}$ chamber.

A. Younger age group $(n: 11)$. 
Table 9. Pre- and post-immersion vibratory sensibilities (mean $\mathrm{dB} \pm \mathrm{s}$. D.) at $250 \mathrm{~Hz}$ in $30^{\circ} \mathrm{C}$ room

\begin{tabular}{|c|c|c|c|c|c|}
\hline Subject group & (No. exam.) & Hand & Pre-immersion & Post-immersion & Paired $t$ test \\
\hline \multirow[t]{3}{*}{ Younger } & (11) & Right (immersed) & $2.1 \pm 4.4$ & $26.1 \pm 8.4$ & $P<0.001$ \\
\hline & & Left & $1.6 \pm 3.7$ & $2.3 \pm 3.8$ & n. s. \\
\hline & & Paired $t$ test & n.s. & $P<0.001$ & \\
\hline \multirow[t]{3}{*}{ Older } & $(10)$ & Right (immersed) & $5.0 \pm 6.1$ & $24.5 \pm 11.7$ & $P<0.001$ \\
\hline & & Left & $4.5 \pm 5.9$ & $2.8 \pm 5.9$ & n.s. \\
\hline & & Paired $t$ test & n.s. & $P<0.001$ & \\
\hline
\end{tabular}

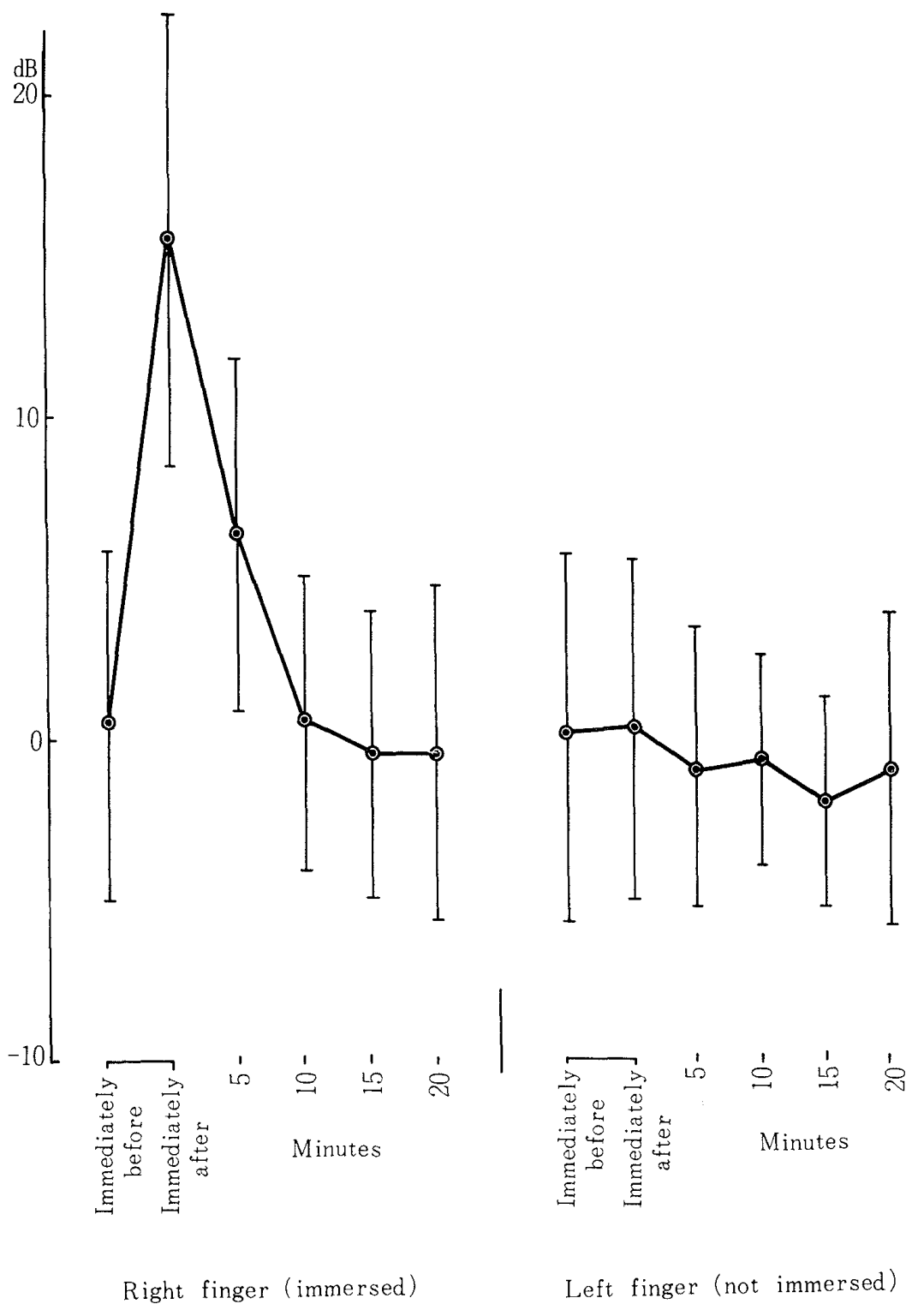

Fig. 8. Changes of vibratory sensibilities (at $125 \mathrm{~Hz}$ ) through cold water immersions in $30^{\circ} \mathrm{C}$ chamber. B. Older age group $(n: 10)$. 
Table 10. Recovery of digital temperatures of immersed fingers within 40 minutes after finishing immersions

A. Younger age group ( $\mathrm{n}: 11)$

\begin{tabular}{ccc} 
& \multicolumn{2}{c}{ Recovery } \\
Room temp. & No & Yes \\
\hline $10^{\circ} \mathrm{C}$ & 6 & 5 \\
$30^{\circ} \mathrm{C}$ & 0 & 11
\end{tabular}

Fischer's direct calculation $P<0.03$
B. Older age group ( $n: 10)$

\begin{tabular}{ccc} 
& \multicolumn{2}{c}{ Recovery } \\
\cline { 2 - 3 } Room temp. & No & Yes \\
\hline $10^{\circ} \mathrm{C}$ & 6 & 4 \\
$30^{\circ} \mathrm{C}$ & 0 & 10 \\
\hline$P<0.03$ & &
\end{tabular}

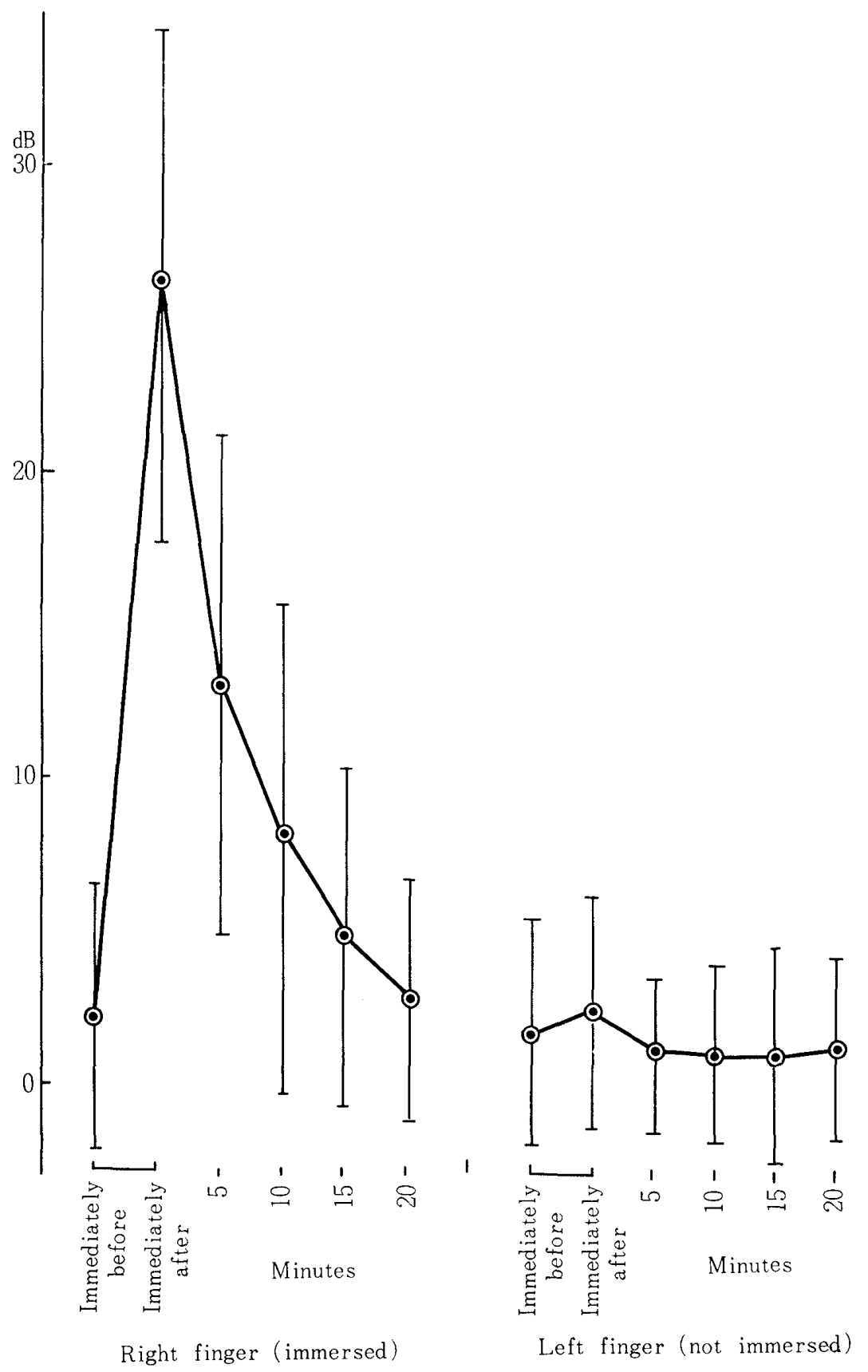

Fig. 9. Changes of vibratory sensibilities (at $250 \mathrm{~Hz}$ ) through cold water immersions in $30^{\circ} \mathrm{C}$ chamber. A. Younger age group ( $\left.n: 11\right)$. 
Table 11. Recovery of pinch strengths $(\mathrm{kg})$ of immersed finger within 20 minutes after finishing immersions

A. Younger age group $(n: 8)$

\begin{tabular}{ccc} 
& \multicolumn{2}{c}{ Recovery } \\
\cline { 2 - 3 } Room temp. & No & Yes \\
\hline $10^{\circ} \mathrm{C}$ & 6 & 2 \\
$30^{\circ} \mathrm{C}$ & 4 & 4 \\
\hline
\end{tabular}

Fischer's direct calculation

n. s.
B. Older age group $(n: 7)$

\begin{tabular}{ccc} 
& \multicolumn{2}{c}{ Recovery } \\
Room temp. & No & Yes \\
\hline $10^{\circ} \mathrm{C}$ & 5 & 2 \\
$30^{\circ} \mathrm{C}$ & 1 & 6 \\
\hline
\end{tabular}

Table 12. Recovery of vibratory sensibilities (dB at $125 \mathrm{~Hz}$ ) within 20 minutes after finishing immersion. A. Younger age group ( $\mathrm{n}: 11$ )

1. Right finger (immersed)

\begin{tabular}{ccc} 
& \multicolumn{2}{c}{ Recovery } \\
\cline { 2 - 3 } Room temp. & No & Yes \\
\hline $10^{\circ} \mathrm{C}$ & 9 & 2 \\
$30^{\circ} \mathrm{C}$ & 1 & 10
\end{tabular}

Fischer's direct calculation $P=0.001$
2. Left finger (not immersed)

\begin{tabular}{ccc} 
& \multicolumn{2}{c}{ Recovery } \\
\hline Room temp. & No & Yes \\
\hline $10^{\circ} \mathrm{C}$ & 7 & 4 \\
$30^{\circ} \mathrm{C}$ & 4 & 7 \\
\hline
\end{tabular}

n. s.

Table 13. Recovery of vibratory sensibilities ( $\mathrm{dB}$ at $125 \mathrm{~Hz}$ ) within 20 minutes after finishing immersions. B. Older age group ( $\mathrm{n}: 10$ )

1. Right finger (immersed)

\begin{tabular}{ccc}
\hline & \multicolumn{2}{c}{ Recovery } \\
\hline Room temp. & No & Yes \\
\hline $10^{\circ} \mathrm{C}$ & 8 & 2 \\
$30^{\circ} \mathrm{C}$ & 3 & 7 \\
\hline
\end{tabular}

Fischer's direct calculation $P=0.05$
2. Left finger (not immersed)

\begin{tabular}{ccc} 
& \multicolumn{2}{c}{ Recovery } \\
Room temp. & No & Yes \\
$10^{\circ} \mathrm{C}$ & 10 & 0 \\
$30^{\circ} \mathrm{C}$ & 1 & 9 \\
$P<0.0005$ & &
\end{tabular}

Table 14. Recovery of vibratory sensibilities (dB at $250 \mathrm{~Hz}$ ) within 20 minutes after finishing immersions. A. Younger age group ( $\mathrm{n}: 11)$

1. Right finger (immersed)

\begin{tabular}{ccc}
\hline & \multicolumn{2}{c}{ Recovery } \\
\cline { 2 - 3 } Room temp. & No & Yes \\
\hline $10^{\circ} \mathrm{C}$ & 8 & 3 \\
$30^{\circ} \mathrm{C}$ & 3 & 8
\end{tabular}

Fischer's direct calculation $P=0.05$
2. Left finger (not immersed)

\begin{tabular}{ccc}
\hline & \multicolumn{2}{c}{ Recovery } \\
\cline { 2 - 3 } Room temp. & No & Yes \\
\hline $10^{\circ} \mathrm{C}$ & 7 & 4 \\
$30^{\circ} \mathrm{C}$ & 5 & 6 \\
\hline
\end{tabular}

n. s. 
Table 15. Recovery of vibratory sensibilities ( $\mathrm{dB}$ at $250 \mathrm{~Hz}$ ) within 20 minutes after finishing immersions. B. Older age group ( $\mathrm{n}: 10)$

1. Right finger (immersed)

\begin{tabular}{ccc}
\hline & \multicolumn{2}{c}{ Recovery } \\
Room temp. & No & Yes \\
\hline $10^{\circ} \mathrm{C}$ & 6 & 4 \\
$30^{\circ} \mathrm{C}$ & 3 & 7
\end{tabular}

Fischer's direct calculation n. s.
2. Left finger (not immersed)

\begin{tabular}{crc}
\hline & \multicolumn{2}{c}{ Recovery } \\
\hline Room temp. & No & Yes \\
\hline $10^{\circ} \mathrm{C}$ & 10 & 0 \\
$30^{\circ} \mathrm{C}$ & 2 & 8 \\
\hline$P<0.003$ & &
\end{tabular}

\section{Discussion}

Saito (1980) reported that there are no significant differences of digital temperatures among each age decade. However, the digital temperatures of the older age group tended to be a little higher than those of the younger age group, especially a significant difference was detected in the left hands only in the $10^{\circ} \mathrm{C}$ chamber $(P<0.05)$ (Table 2).

In the $10^{\circ} \mathrm{C}$ chamber, the $6.5^{\circ} \mathrm{C}$ water immersion also reduced the digital temperatures on the non-immersed side. Cold vasodilatations could be observed in only a few cases in this study. The vosodilatation occurs in the skin of the finger after the latter has been immersed in water at $18^{\circ} \mathrm{C}$ or $15^{\circ} \mathrm{C}$ or lower for 5 to 10 minutes in a room temperature of $19^{\circ} \mathrm{C}$ to $21.5^{\circ} \mathrm{C}$ (Lewis, 1930). However, under the strict conditions outlined above, only five fingers of the younger age group and four of the older age group were able to show these cold vasodilatations. Although the authors thought that hunting reactions are attributed to an axon reflex in the sensory nerves, the reactions seemed to be unexpectedly difficult to induce (Suzuki et al., 1980). The digital temperatures of the immersed fingers recovered more smoothly in the $30^{\circ} \mathrm{C}$ chamber within 40 minutes than in the $10^{\circ} \mathrm{C}$ chamber $(P<0.03)$. In a colder room, thermal recoveries of immersed fingers of healthy persons seemed to be unexpectedly slow (Table 10).

Pinch strengths did not show any changes between the two groups. However, the pinch strengths of the right hands were reduced through the immersions, significantly in the $10^{\circ} \mathrm{C}$ chamber. Coppin et al. (1978) reported that grip strength significantly decreased as a consequence of immersion $\left(10^{\circ} \mathrm{C}\right.$ water) of the forearm. Rapid cooling contractures of the intrinsic muscles seemed to be responsible for significantly reducing pinch strengths. These effects had a tendency to continue for some minutes in the $10^{\circ} \mathrm{C}$ chamber, and in the younger age group, even in the $30^{\circ} \mathrm{C}$ chamber. In the older age group, the pinch strengths recovered significantly in the $30^{\circ} \mathrm{C}$ chamber $(P<0.05)$ (Table 11).

As to vibratory sensibilities $(\mathrm{dB}$ at $125 \mathrm{~Hz}$ ), there were no significant differences between the two age groups. As a result of the immersions, these vibratory sensibilities became lowered even in the non-immersed fingers only in the $10^{\circ} \mathrm{C}$ chamber. These changes in the $10^{\circ} \mathrm{C}$ chamber seemed to be quite similar to those of the digital temper- 
atures. Dorfman \& Bosley (1979) reported that, in adult humans, peripheral nerve conduction velocity slows with advancing age at the rate of approximately $-0.15 \mathrm{~m} / \mathrm{sec}$ per year for motor fibers and of $-0.16 \mathrm{~m} / \mathrm{sec}$ per year for sensory fibers. On the other hand, it has been demonstrated by Goodgold \& Eberstein (1977) that both motor and sensory conduction velocities may be lowered by 2 to $2.4 \mathrm{~m} / \mathrm{sec}$ for each $1^{\circ} \mathrm{C}$ drop in temperature. Omer (1974) reported that these receptor organs vary with age, region of the body and occupation, and are constantly dying or being destroyed. The authors concluded that these changes of the vibratory sensibilities are intimately related to vascular changes and blood flows, without involving neural elements. In the $30^{\circ} \mathrm{C}$ chamber, only the immersed fingers were affected by the immersions. Recoveries of the immersed fingers were significantly smooth only in the $30^{\circ} \mathrm{C}$ chamber $(P<0.05)$ (Tables 12 and 13). The non-immersed fingers also recovered more smoothly in the $30^{\circ} \mathrm{C}$ chamber, significantly in the older age group.

Vibratory sensibilities ( $\mathrm{dB}$ at $250 \mathrm{~Hz}$ ) were significantly affected in the immersed fingers. However, the non-immersed fingers in the $10^{\circ} \mathrm{C}$ chamber were affected only in the older age group. In the $30^{\circ} \mathrm{C}$ chamber, vibratory sensibilities of both groups were similarly affected by the immersions. The relationships among the recovery of these sensibilities, the room temperatures and the immersions were significant in the right fingers of the younger age group and in the left fingers of the older age group (Tables 14 and 15).

Although Omer (1974) reported that the best threshold for detecting vibration is oscillatory stimulation at 200 to $250 \mathrm{~Hz}$, the authors concluded that the most useful stimulation seemed to be at $125 \mathrm{~Hz}$.

\section{Acknowledgement}

This work was supported by a grant from a project in science of industrial ecology. The authors gratefully acknowledge the contribution of Prof. Keizo Shiraki, Miss Yoshie Yamanaka and Miss Reiko Sekihara who assisted in the preparation of the experiment. This paper was presented at the 24th annual meeting of Japan Society for Surgery of the Hand.

\section{References}

Coppin, E. G., Livingstone, S. D. \& Kuehn, L. A. (1978): Effects on handgrip strength due to arm immersion in a $10^{\circ} \mathrm{C}$ water bath. Aviat. Space Environ. Med., 49: 1322-1326.

Dorfman, L. J. \& Bosley, T. M. (1979): Age-related changes in peripheral and central nerve conduction in man. Neurology, 29: 38 44.

Goodgold, J. \& Eberstein, A. (1977) : Electrodiagnosis of Neuromuscular Diseases. 2nd ed. Williams \& Wilkins, Baltimore. pp. 110-111.

Lewis, 'T. (1930): Observations upon the reactions of the vessels of the human skin to cold. Heart, 15: 177-208. 
Omer, G. E., Jr. (1974): Sensation and sensibility in the upper extremity. Clin. Orthop. Relat. Res. , 104: 30-35.

Saito, K. (1980): Vibration Hazards as an Occupational Disease. 1st ed. Nankodo, Tokyo, pp. $36-38$.

Suzuki, K., Ijichi, M., Kondo, M. et al. (1980): Digital temperature response to a cold water immersion in various nerve injuries. J. UOEH, 2: 339-345.

Suzuki, K., Ijichi, M., Matsuki, T. et al. (1981): The hand and environment. J. UOEH, 3: $109-115$.

手と環境(2)

- 2 環境条件下で, 冷水浸漬負荷を行った 2 年令群の手の機能の生理学的変動一

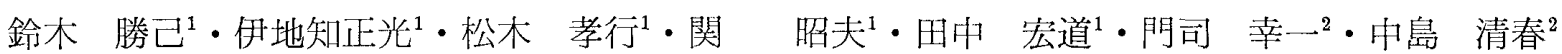
1産業医科大学整形外科学教室 20産業医科大学人工気象室

要旨：手の種々の機能の数量表示が行われて来ている. 然し，てれ等の正常值が色々な環境や個 人の条件で, どう変動するかの報告は少ない。そてで一連の基礎的な生理学的な実験を 行った. 手の種々の機能の中で 3 つの示標を選んだ. 即ち, 指皮温, 指振動覚, ピンチ力.

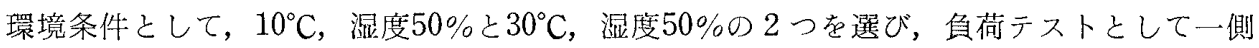
手の冷水浸債を夫々の環境下で，21 健康成人男子に実施し，3示標の経時変動を測定した 指皮温は，高令群で稍高く，浸漬手指皮温の 40 分間後の回復は， $30^{\circ} \mathrm{C}$ 室内で，ょり円滑， 浸漬手のピンチ力は，減少し，乙れは， $10^{\circ} \mathrm{C}$ 穻内で著明．指振動覚は同様に浸漬手指で鈍 麻化した。

J. UOEH（産業医大誌)，3 (4)：347-362（1981） 